DOI 10.18551/rjoas.2019-11.31

\title{
THE ASSOCIATION OF INCREASING HUMAN DEVELOPMENT INDEX WITH REDUCTION OF POVERTY IN CENTRAL SULAWESI, INDONESIA
}

\author{
Patta Tope \\ Faculty of Economics and Business, University of Tadulako, Palu, Indonesia \\ E-mail: pattatope@yahoo.com
}

\begin{abstract}
A research on the link to increasing the Human Development Index (HDI) with poverty was carried out in Central Sulawesi in the period of 2010-2018. Some research results show that the relationship between the two variables was significant in a country/region, but there are also some that are not significant in a particular country/region. In an effort to get the desired results, the analysis method used regression. From the calculation results obtained HDI has a negative and significant effect on the percentage of population in Central Sulawesi in the period of 2010-2018, meaning that an increase in HDI will reduce the percentage of poor people in Central Sulawesi. Thus, the increase in HDI in Central Sulawesi illustrated by three aspects, namely the improvement of health status has touched most of the poor people, education has been enjoyed and felt by most poor people and a decent standard of living in Central Sulawesi has been felt by most of the community with low income. The results of this research can later be used by various groups, especially the Central Sulawesi regional government to continue to boost the increase in HDI in order to reduce poverty.
\end{abstract}

\section{KEY WORDS}

Education, health, poverty, Central Sulawesi, public service.

One measure of socio-economic conditions in assessing the success of development carried out by the government in a country/region is a decrease in poverty (Muralimohan and Devarajulu, 2017). The lower the poverty rate of a country/region, the less negative impact is produced. The poverty rate which tends to decrease slowly shows that the poverty reduction strategy undertaken by the government of a country/region is not optimal. The Central Statistics Agency (2019) measures poverty by using the concept of ability to meet basic needs (basic needs approach). With this approach, poverty is seen as an inability on the economic side to meet the basic needs of food and non-food measured from the expenditure side. This measurement is carried out by looking at the amount of rupiah spent per capita per month to meet the minimum food and non-food needs. The 2,100 calorie measure per day is used to benchmark food needs while for non-food needs includes spending on housing, clothing, and various goods and services.

One of the main causes of poverty in an area is the low quality of human resources. Good or bad quality of human resources, among others, can be seen from the value (HDI). This index was developed in 1990 by Indian Nobel laureates, Amartya Sen and Mahbub UI Haq, a Pakistani economy and has since been used by the UN development program in its annual report (Mcneill, 2007). This index is more focused on things that are more sensitive and useful than just the per capita income that has been used. This index is also useful as a bridge to find out more detailed things in making reports on the development of human development. HDI is intended to measure the impact of efforts to improve these basic capabilities. Thus HDI uses impact indicators as a basic component of its calculation, namely life expectancy at birth, educational attainment as measured by the expected average length of schooling and average length of schooling, and consumption expenditure. A very interesting thing to observe is Central Sulawesi HDI in 2010 amounted to 63.29 points, increased to 68.88 points in 2018 or an increase of 5.59 points, while the percentage of poor people in 2010 amounted to 18.07 percent, decreased to 13.69 percent in 2018 or a reduction in the percentage of poor people by 4.38 percent. 
The development of human capabilities will determine an increase in the quality of life of the population physically, mentally and spiritually (Seth, 2013). Explicitly, it is stated that the development carried out focused on the development of human resources in line with economic growth and poverty reduction. Development of human resources physically and mentally implies an increase in the basic capacity of the population which will then enlarge opportunities to be able to participate in the development process as part of the rights to obtain income, health and education (Klugman, Rodriguez and Choi, 2011). The level of education and public health that is good enough results in an increase in community productivity. Conditions like this will also increase spending on consumption which will ultimately reduce the level of poverty in the community. The results of this study are expected to be utilized by the Central Sulawesi regional government to continue to prioritize programs that support the increase in HDI in order to reduce poverty.

\section{LITERATURE REVIEW}

The role of government, especially in improving HDI is one of the new paradigms in development that emphasizes the importance of aspects of education, health and to increase human productivity (Iskandar, 2017). Many countries and regions are investing in education and health to improve the quality of human resources as evidenced by the increase in knowledge and skills and the degree of health of a person. The higher the level of education and health status of a person, the knowledge and expertise will increase at the same time accompanied by an increase in work productivity.

The private sector and the government will get more results by employing workers with high productivity so that the community will also get a salary from the company and the government more. In employment in the informal sector such as agriculture, improving the skills and expertise of the workforce will be able to increase agricultural output because skilled workers are able to work more efficiently. High productivity in the community will result in an increase in income and consumption, which in turn improves the standard of living (Suna and Korkmaz, 2017).

Improving human quality in Indonesia is synonymous with poverty reduction. Increasing the budget in the fields of education and health will be more meaningful for the poor than for the non-poor, because for the poor the main asset is their rough labor. The availability of inexpensive education and health facilities will greatly help to increase productivity, and ultimately increase income (Feriyanto, 2016).

The level of health and education in society can affect poverty. Improvements in the health sector by a country/regional government can increase community productivity (Elistia and Syahzuni, 2018). School-age residents can attend school and receive lessons well. A high level of education in the community will cause workers to have sufficient skills and knowledge so that productivity increases and income also increases.

If seen from the experience of several developing countries, as well as advanced countries, there is an important relationship between HDI and productive income capacity. Revenue is the main determinant and result of human development of a country/region. People who are economically disadvantaged use their energy to participate in economic growth, but the inability caused by low levels of education, and poor nutrition and health will reduce their capacity to work (Noorbakhsh, 1998). Therefore the low HDI causes poor people to not be able to take advantage of the opportunities for productive income from the progress of economic development. Therefore the provision of basic social services, especially education and health, is an important element in overcoming poverty in society.

Community income and HDI have a reciprocal relationship (Aktas and Karagoz, 2015) although revenue growth in the community does not automatically increase HDI. Likewise, improvements in health and education levels that cause an increase in HDI do not always lead to improvements in income. This phenomenon is caused by the resources generated by economic growth that are not automatically used to improve other fields, for example the structure and process of development improvements that occur in the community cannot benefit the poor. Increasing agricultural production, for example, only benefits landowners 
and not labor. The poor will be able to benefit from the growth of government revenue and increasing $\mathrm{HDI}$, if the government uses an increase in the budget to finance health services and access to education. Therefore the structure and process of community empowerment in the fields of education and health must be precise, so that the benefits of economic growth are also enjoyed by the poor (Cherchye, Ooghe and Puyenbroeck, 2008)

Several studies have been carried out in various regions in Indonesia proving that HDI affects poverty levels including Prasetyoningrum and Sulia Sukmawati research showing that HDI has a negative and significant effect on poverty levels in Indonesia (Prasetyoningrum and Sukmawati, 2018). However, there are also a number of studies stating that HDI has no significant effect on poverty levels in Indonesia (Prasetyoningrum and Sukmawati, 2018) towards poverty and it is stated that there is no causal relationship between IPM and poverty in Indonesia (Syaifullah and Malik, 2017). It is wrong to assume that increasing HDI will reduce poverty rates in all countries / regions. This study seeks to see whether there is an influence on the level of HDI development with a decrease in poverty in Central Sulawesi.

\section{METHODS OF THE RESEARCH}

This research used quantitative analysis included the collection and processing of secondary data in the form of time series on HDI values and the percentage of poor people in Central Sulawesi from 2010 to 2018, the data of which were obtained from the Central Statistics Agency of Central Sulawesi.

The first regression equation model $Y_{1}=A X_{i}^{B i} E$ transformed in the form of $\mathrm{Ln}$ so that it becomes linear as follows:

$$
\operatorname{Ln} Y=\beta 0+\beta_{1} \operatorname{Ln} X_{1}+\varepsilon
$$

Where: $Y=\mathrm{HDI}$ in Central Sulawesi Province; $X_{1}=$ Percentage of Poor Population in Central Sulawesi; $\beta o=$ Constant; $\beta_{1}=$ Regression coefficient, as well as elasticity; $\varepsilon=$ Epsilon.

To test the hypothesis the regression coefficient $(\beta)$ is carried out with the following steps: formulating hypothesis; determining the Level of Significant (LOS) on $\alpha=0,01$ or $\alpha=0,05$; determining the value of $t$-counted.

$$
\begin{gathered}
\mathrm{t} \text {-counted }=\frac{\beta}{S \beta} \\
\mathrm{S} \beta=\frac{S e}{\sqrt{\sum\left(X^{2}\right)-\left(\sum X\right)^{2} / n}} \\
\mathrm{~S}_{\mathrm{e}}=\sqrt{\frac{\sum Y^{2}-a \sum Y-\beta \sum X Y}{n-2}}
\end{gathered}
$$

Making decision to the hypothesis; by comparing the t-counted value with the t-table value: If the t-counted $\leq t$-table $\alpha / 2(n-k)$ then $H o$ is accepted; If the t-counted $>t$-table $\alpha / 2(n-$ k) then $\mathrm{Ho}$ is rejected.

To measure the magnitude of the variation in the effect of the development of the Central Sulawesi IPMS value on the percentage of the poor population the coefficient of determination (R2) is used.

Calculations using the regression analysis model formula (Rencher and Schaalje, 2008), then the data processing is done using a computer facility with the help of a professional statistical data processing program or SPSS (Statistical Product and Service Solution) v.19.

\section{RESULTS AND DISCUSSION}

The 2018 BPS official report shows that the Central Sulawesi HDI continues/is progressing. In 2010 the Central Sulawesi HDI value of 63.29 points, and always increasing 
every year. In 2018 the Central Sulawesi HDI value reached 68.88 points or an increase of 5.59 points compared to the HDI value in 2010 (see figure 1). This development was caused by the increase in the components of HDI, namely the increase in life expectancy at birth from 66.07 points in 2010 to 67.78 in 2018, the increase in the Old School Expectation Rate from 11.70 points in 2010 to 13.13 points in in 2018, the increase in average length of schooling from 7.65 points in 2010 to 8.51 points in 2018 and an increase in per capita population expenditure per year from Rp. 7,988,000 in 2010 to Rp. 9,888,000 in 2018 (see figure 1 below).

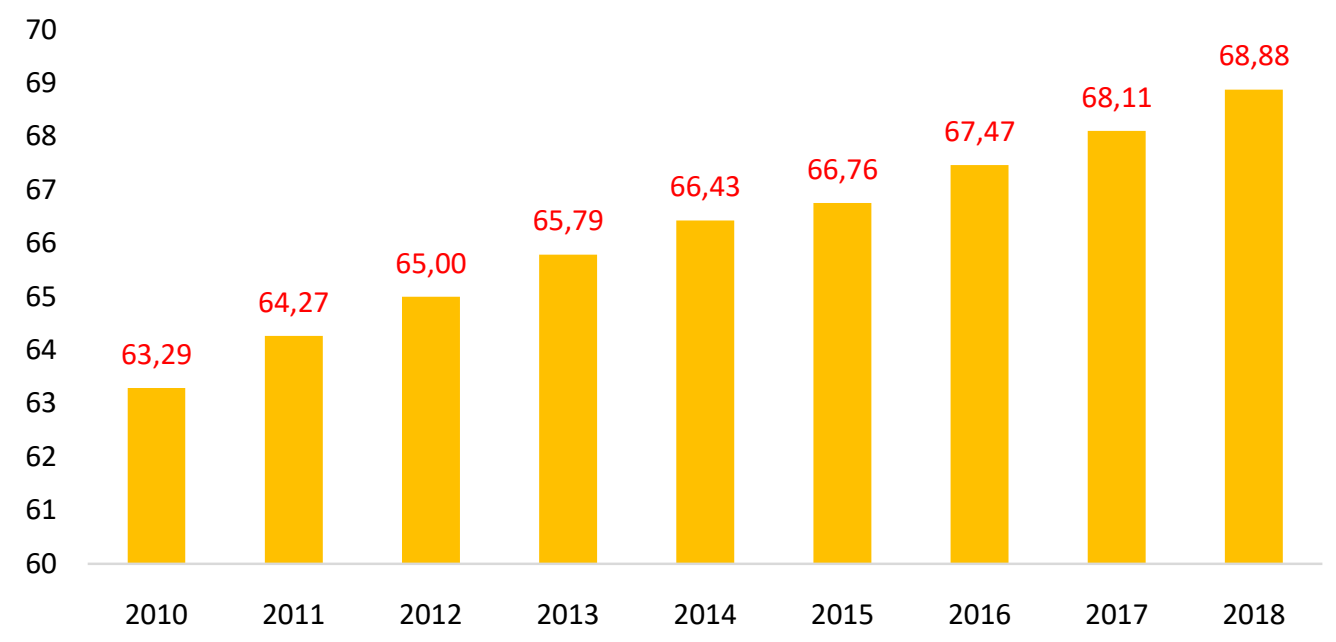

Figure 1 - The Score of HDI Source: Data Processed, 2019

Furthermore, according to the Central Statistics Agency (BPS) of Central Sulawesi, poverty rates have indeed been relatively declining. But the movement from year to year is very slow. The slowness in overcoming poverty can be seen from the movement of the population of poor people in 2010 up to 2018. The percentage of poverty in Central Sulawesi in 2010 was recorded at 18.07 percent, in 2011 it was recorded at 16.04 percent in 2012 recorded at 14.94 percent, at in 2013 it was recorded 14.32 percent, in 2014 it was recorded 13.61 percent, in 2015 it was 14.07 percent, in 2016 it was 14.09 percent, in 2017 it was 14.22 percent and in 2018 it was recorded 13.69 percent (see figure 2). When referring to the development of $\mathrm{HDI}$, this condition is not proportional to the decrease in the percentage of poor people that looks very slow, even though the government has issued many budgets for poverty alleviation.

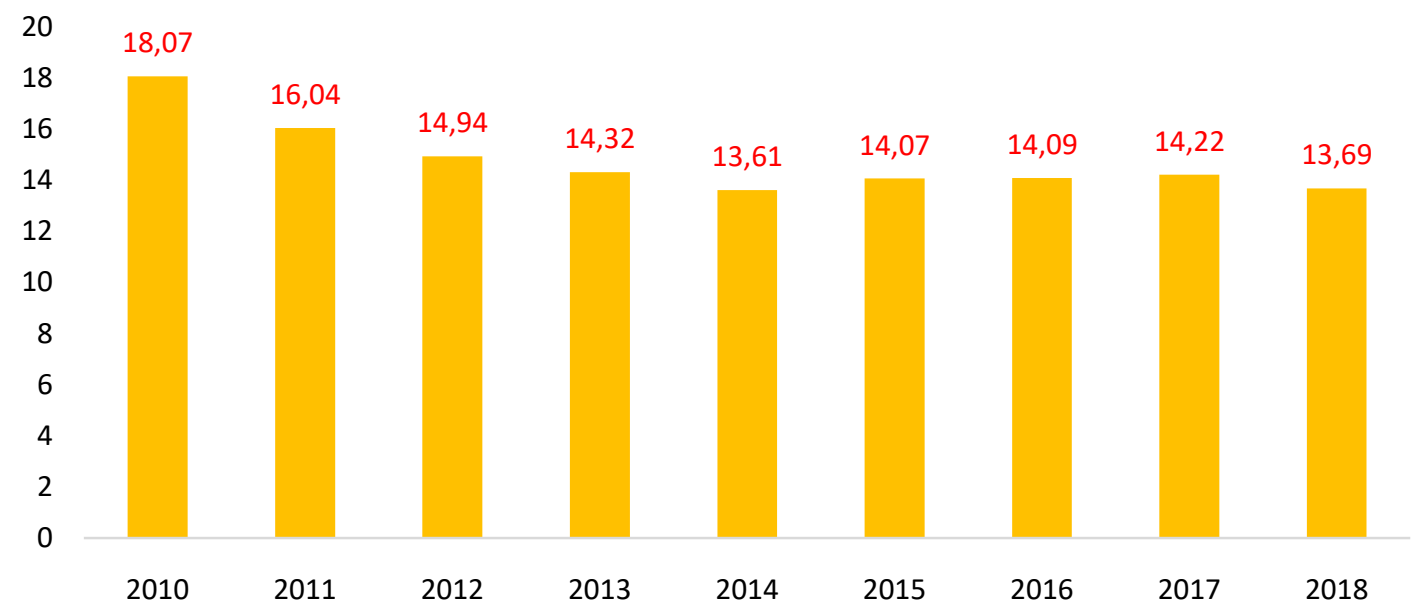

Figure 2 - Poverty (percent) Source: Processed Data, 2019 
The link of HDI with poverty, in improving the quality of development of a country, human resources with good quality is needed. Increasing the education and health budget is expected to improve the quality of human resources. This increase will increase labor productivity, especially labor at lower levels, which in turn can reduce poverty.

After testing based on regression analysis it was found that HDI had a negative effect (2.82) and was significant for poverty levels in Central Sulawesi. This means that every 1 percent increase in HDI will reduce the percentage of poor people by 2.82 percent. Significance test results were accepted at 95 percent confidence level, with a coefficient of 0.85 percent dissemination, meaning that 85 percent of poverty reduction was caused by changes in the model (HDI) while the rest was caused by factors outside the model. This shows that the increase in the Human Development Index (HDI) has an effect on reducing the level of poverty in Central Sulawesi in the period of 20010-2018. That means an increase in HDI in Central Sulawesi, which is illustrated by three aspects, namely first: life expectancy in the sense of improving health status in Central Sulawesi has touched most of the poor, secondly; education has been enjoyed and felt by most poor people and the third, the standard of decent living in Central Sulawesi is relatively sufficient among low-income people.

In order to make education spending more effective, the increase in the education budget needs to be directed at improving quality, both to improve the quality of teaching staff, the curriculum and the teaching-learning process. Another effort that must also be made is to increase education spending on vocational education. The improvement is not just adding buildings or equipment but also touching the curriculum so that the material being taught can reduce the mismatch between the world of education and the job market. In addition, the adequacy of the health budget must also be considered in order to improve and improve health services.

\section{CONCLUSION}

Central Sulawesi HDI from 2010 to 2018 increased continuously, while the percentage of poor population from the same period was relatively decreasing. Based on the regression results it was found that the HDI has a negative and significant effect on the level of Poverty in Central Sulawesi in the period 2010-2018. Thus the increase in HDI in Central Sulawesi illustrated by the improvement of health status has touched most of the poor, education has been enjoyed by most of the poor and the standard of decent living in Central Sulawesi is relatively sufficient among low-income people. For this reason, efforts must be made to improve the quality and quantity of the education and health budget in the context of poverty alleviation in Central Sulawesi.

\section{REFERENCES}

1. Aktas S., Karagoz D., Trends in Human Development Index of European Union, The Online Journal of Science and Technology, Vol.5, October 2015, pp. 69-79.

2. Cherchye I., Ooghe E., Van Puyenbroeck T., Robust Human Development Rankings, Jounal of Economic Inequality, Vol. 6, Desember 2008, pp. 287-321.

3. Elistia El., Syahzuni B A., The Correlation OF The Human Development Index (HDI) Towards Economic Growth (GDP Per Capita) in 10 ASEAN Member Countries, Journal Of Humanities and Social Studies, Vol. 02, September 2018, pp. 40-46.

4. Feriyanto N. The Effect of Employment, Economic Growth, and Investment on HDI: In Provinces in Indonesia, Journal of Economics, Business, and Accountancy Ventura, Vol. 19, April - July 2016, pp. $1-12$.

5. Iskandar I, Effect of Human Development Index Fund on Economic Growth Through a Special Autonomy, Jurnal Ekonomi Pembangunan, 18 (1), 2017, pp. 40-49.

6. Klugman J., RodriguezJ., Choi H., The HDI 2010: New Controversies, Old Critiques, The Jounal of Economic Inequality, Vol. 9, June 2011, pp. 249-288. 
7. Mcneill D., Human Development: The Power of the Idea, Journal of Human Development and Capabilities Vol. 8(1): March 2007, pp.5-22.

8. Muralimohan M., Devarajulu M., Role of Micro Credit in Poverty Eradication: A Case Study in Chittoor Rural Mandal Of Andhra Pradesh, Asian Journal for Poverty Studies, Vol 3, 2017, pp. 87-94.

9. Noorbakhsh F., The Human Development Index: Some Technical Issues And Alternative Indices, Journal of International Development, Vol. 10, 1998 pp. 589-605.

10. Rencher, A.C. \& Schaalje, G. B. 2008. Linear Models Statistics 2nd Edition, John and Sons, Inc, Hoboken, New Jersey.

11. Seth S., A Class of Distribution and Association Sensitive Multidimensional Welfare Indices, Journal of Economic Inequality, Vol. 11, June 2013, pp 133-162.

12. Syaifullah A., Malik N., Pengaruh Indeks Pembangunan Manusia dan Produk Domestik Bruto Terhadap Tingkat Kemiskinan di ASEAN-4 (Studi Pada 4 Negara ASEAN), Jurnal Ilmu Ekonomi, Vol. 1, 2017, pp. 107 - 119.

13. Statistic of Sulawesi Tengah Province, 2019. Sulawesi Tengah Province in Figures 20112018, Palu, Sulawesi Tengah.

14. Suna K., Korkmaz O., The Relationship Between Labour Productivity and Economic Growth in OECD Countries, International Journal of Economics and Finance; Vol. 9, No. 5; 2017, pp. 71-76.

15. Prasetyoningrum AK. Sulia Sukmawati U., Analisis Pengaruh Indeks Pembangunan Manusia (IPM), Pertumbuhan Ekonomi dan Pengagguran Terhadap Kemiskinan di Indonesia., EQUILIBRIUM: Jurnal Ekonomi Syariah Vol. 6, 2018, pp. 217 - 240. 